\title{
HUBUNGAN OBESITAS DENGAN PENINGKATAN ASAM URAT PADA REMAJA DI SEKOLAH MENENGAH PERTAMA
}

\author{
Edwin Zaofery Sipayung \\ Sarah. M. Warouw \\ Jeanette. I. Ch. Manoppo
}

\begin{abstract}
Bagian Ilmu Kesehatan Anak Fakultas Kedokteran Universitas Sam Ratulangi Manado

Email ; edwinzaofery_sipayung@yahoo.com
\end{abstract}

Background: Obesity is a serious and growing problem for healthcare systems in the world. Obesity is caused by various factors. The most common causes are genetic factors, lack of physical activity or a combination of these factors. If not treated immediately it will have a negative impact on human health in the short term or long term. Uric acid itself is the end product of purine metabolism in humans. The cause of the increased uric acid levels are influenced by various factors example genetic, hypothyroidism, obesity, high diet purine. Objective: To know the correlation between obesity and the increase of uric acid in teenagers. Methods: This research used a observational analytic designed with cross sectional approach by consecutive sampling from November to December 2013. There were 30 adolescents who are obese in this study. Result: The results showed, that there are equal amount of adolescent boys (50\%) and girls (50\%). There were 16 adolescents (53.33\%) as the largest group that belongs to 14 years old. There are 10 (30\%) of adolescents that has a body mass index of 28, and it has the most number of adolescents compared to other body mass index groups. Uric acid test results found an increased uric acid in 15 teens (50\%), and the other 15 teens (50\%) without an increased uric acid. Conclusion: There is no relationship between obesity and an increased uric acid, mostly found in girls adolescent fourteen years old.

Key words: Obesity, Uric acid, Adolescent

Latar belakang: Obesitas merupakan masalah yang serius dan berkembang untuk sistem kesehatan di dunia. Obesitas diakibatkan oleh berbagai faktor. Penyebab paling umum adalah faktor genetik, kurangnya aktivitas fisik atau kombinasi dari faktor-faktor ini. Jika tidak segera ditangani maka akan berdampak buruk pada kesehatan manusia dalam jangka pendek ataupun jangka panjang. Asam urat sendiri merupakan produk akhir metabolisme purin pada manusia. Penyebab meningkatnya kadar asam urat dipengaruhi oleh berbagai macam faktor contohnya genetik, hipotiroid, obesitas, diet tinggi purin. Tujuan penelitian: Untuk mengetahui hubungan obesitas dengan peningkatan asam urat pada remaja. Metode: Penelitian ini menggunakan desain penelitian observasional analitik dengan pendekatan cross sectional yang dilakukan dengan cara consecutive 
sampling dari bulan November sampai Desember 2013. Sampel penelitian berjumlah 30 remaja yang mengalami obesitas. Hasil penelitian: Hasil penelitian didapatkan, 15 remaja perempuan (50\%) dan 15 remaja laki-laki (50\%). Kelompok umur terbanyak adalah 14 tahun berjumlah 16 remaja (53,33\%). Terdapat 10 remaja (30\%) yang memiliki indeks massa tubuh 28, dan golongan tersebut memiliki jumlah remaja terbesar dibandingkan golongan indeks masa tubuh lainnya. Hasil pemeriksaan asam urat ditemukan peningkatan sebanyak 15 remaja (50\%), dan yang tidak mengalami peningkatan sebanyak 15 remaja (50\%). Kesimpulan: Tidak ada hubungan antara obesitas dengan peningkatan asam urat, sebagian besar ditemukan pada remaja perempuan yang berumur empat belas tahun.

\section{Kata kunci : Obesitas, Asam urat, remaja}

Obesitas mempengaruhi semua kelompok usia termasuk anak serta remaja. Obesitas merupakan masalah yang serius dan berkembang untuk sistem kesehatan di dunia. Peningkatan jumlah prevalensi yang pesat disertai dengan meningkatnya jumlah penderita diabetes tipe 2, hipertensi, hiperlipidemia dan sindrom metabolik. Dengan peningkatan dramatis dalam prevalensi obesitas, dokter primer ditempatkan di garis depan memberikan pelayanan kesehatan kepada anak-anak dan remaja obesitas. ${ }^{1}$

Data baru yang dikumpulkan oleh Himpunan Obesitas Indonesia (2008) menunjukkan prevalensi obesitas untuk anak-anak pada sejumlah Sekolah Dasar di Indonesia adalah 12\% menderita obesitas dan 9\% kegemukan dari 1.730 anak (Zulfa F, 2011). ${ }^{2}$ Menurut data Riskesdas (2010) sebesar 2,5 \% remaja umur 13 15 tahun masuk dalam kategori gizi gemuk berdasarkan IMT dan remaja umur 16 - 18 tahun sebanyak 1,4 \% masuk dalam kategori gizi gemuk berdasarkan IMT. Pada kategori usia ini pula remaja yang mengalami gizi gemuk lebih banyak pada perempuan $(1,5 \%)$ dibanding pada remaja pria $(1,3 \%) .{ }^{3}$ Pada Sulawesi Utara menurut Riskesdas (2007) presentase anak yang berusia 6-14 tahun dengan berat badan lebih atau obesitas sebesar 8.0 dan pada remaja yang berusia 15 tahun ke atas sebesar $19.10 .^{4}$ Data-data tersebut menunjukkan bahwa masalah kegemukan saat ini menjadi salah satu masalah yang patut diperhatikan oleh kita.

Penyebab anak-anak mengalami obesitas memiliki berbagai alasan. Penyebab paling umum adalah faktor genetik, kurangnya aktivitas fisik, pola makan yang tidak sehat, atau kombinasi dari faktor-faktor ini. Hanya dalam kasus yang jarang obesitas disebabkan oleh kondisi medis seperti masalah hormonal. Pola makan anak dan tingkat aktivitas memainkan peran penting dalam menentukan berat badan anak. Saat ini, banyak anak-anak menghabiskan banyak waktu dengan tidak aktif. Sebagai contoh, rata-rata anak menghabiskan sekitar empat jam setiap hari menonton televisi, komputer dan video game menjadi semakin populer. Jika tidak segera ditangani maka akan berdampak buruk pada kesehatan anak dalam jangka pendek ataupun dalam jangka panjang ${ }^{5,6}$

Untuk mengetahui apakah anak-anak atau remaja mengalami obesitas maka digunakan pengukuran Indeks massa tubuh (BMI) adalah ukuran yang digunakan untuk menentukan kelebihan berat badan dan obesitas masa kanak- 
kanak. Hal ini dihitung menggunakan berat badan anak dan tinggi badan anak. BMI tidak mengukur lemak tubuh secara langsung, tetapi merupakan indikator yang wajar untuk mengukur kegemukan tubuh bagi kebanyakan anak-anak dan remaja. BMI dihitung dengan mengukur berat tubuh dalam kilogram dibagi dengan kuadrat tinggi badan dalam meter. ${ }^{7}$

Asam urat sendiri merupakan produk akhir metabolisme purin pada manusia. Asam urat pertama kali diidentifikasi sekitar 2 abad yang lalu, aspek patofisiologi hyperuricemia masih belum dipahami dengan jelas. Selama bertahun-tahun, hyperuricemia telah diidentifikasi sama dengan gout, namun asam urat kini telah diidentifikasi sebagai penanda untuk sejumlah kelainan metabolik dan hemodinamik. Tingkat serum asam urat normal anak lebih rendah dibandingkan pada orang dewasa. ${ }^{8}$ Menurut penelitian yang dilakukan oleh Oyama C dkk (2006) untuk mengetahui apakah peningkatan kadar asam urat sudah terjadi pada anak dan remaja yang mengalami obesitas. Hasilnya didapatkan bahwa kadar asam urat serum meningkat secara signifikan terhadap mereka yang mengalami obesitas dan dapat digunakan sebagai salah satu indikator yang berhubungan pada awal masa remaja peningkatan asam urat dapat terjadi. $^{11}$

Di Indonesia, penyakit asam urat bahkan terjadi pada usia muda. Hasil data penelitian yang dilakukan seperti Manampiring AE (2011) di kota Tomohon didapatkan prevalensi peningkatan asam urat pada remaja obese di Kota Tomohon adalah sebesar 35 \%. Sementara di Bandungan, Jawa Tengah, prevalensi pada kelompok usia muda, yaitu antara 15-45 tahun,sebesar 0,8\%; meliputi pria 1,7\% dan wanita $0,05 \%$. Penyebab meningkatnya kadar asam urat dipengaruhi oleh berbagai macam faktor contohnya alkohol, genetik, hipotiroid, obesitas, diet tinggi purin. ${ }^{9,10}$

\section{METODE PENELITIAN}

Penelitian ini menggunakan desain penelitian observasional analitik dengan pendekatan cross sectional dari bulan November sampai Desember 2013. Populasi dalam penelitian ini adalah murid laki-laki dan perempuan yang bersekolah di Sekolah Menengah Pertama (SMP) swasta Manado. Pengambilan sampel menggunakan metode consecutive sampling. Kriteria inklusi dalam penelitian ini yaitu murid laki-laki dan perempuan yang tercatat dalam register sekolah, telah mendapat persetujuan dari orang tua murid untuk mengikuti penelitian, murid yang tergolong obesitas. Jumlah sampel dalam penelitian ini adalah 30 remaja yang mengalami obesitas. Variabel dalam penelitian ini adalah obesitas sebagai variabel independen dan asam urat sebagai variabel dependen. 


\section{HASIL PENELITIAN}

Tabel 2. Karateristik asam urat berdasarkan jenis kelamin

\begin{tabular}{ccccc}
\hline Jenis Kelamin & \multicolumn{2}{c}{ Jumlah } & \multicolumn{2}{c}{ Asam Urat Tinggi } \\
& (n) & $\mathbf{( \% )}$ & (n) & (\%) \\
\hline Laki-laki & 15 & 50 & 6 & 40 \\
Perempuan & 15 & 50 & 9 & 60 \\
Total & 30 & 100 & 15 & 100 \\
\hline
\end{tabular}

Berdasarkan tabel 2 dapat dilihat bahwa jumlah sampel yang diteliti pada remaja berdasarkan jenis kelamin adalah sama antara laki-laki dan perempuan. Laki-laki sebesar 15 (50\%) dan perempuan sebesar 15 (50\%). Jumlah yang mengalami peningkatan asam urat berdasarkan jenis kelamin yaitu sebanyak 6 remaja laki-laki (40\%) dan 9 remaja perempuan (60\%).

Tabel 3. Karakteristik asam urat berdasarkan umur

\begin{tabular}{ccccc}
\hline \multirow{2}{*}{ Umur } & \multicolumn{2}{c}{ Jumlah } & \multicolumn{2}{c}{ Asam Urat Tinggi } \\
& $(\mathbf{n})$ & $\mathbf{( \% )}$ & $\mathbf{( n )}$ & $\mathbf{( \% )}$ \\
\hline 12 & 3 & 10 & 1 & 6,7 \\
13 & 10 & 33,33 & 3 & 20 \\
14 & 16 & 53,33 & 10 & 66,6 \\
15 & 1 & 3,33 & 1 & 6,7 \\
Total & 30 & 100 & 15 & 100 \\
\hline
\end{tabular}

Berdasarkan tabel 3 dapat dilihat bahwa golongan umur yang paling banyak menjadi sampel penelitian yaitu umur 14 tahun berjumlah 16 remaja (53,33\%), kemudian diikuti dengan umur 13 tahun berjumlah 10 remaja (33,33\%), 12 tahun berjumlah 3 remaja (10\%), dan yang paling sedikit adalah berumur 15 tahun berjumlah 1 remaja (3,33\%). Untuk jumlah yang mengalami peningkatan asam urat berdasarkan umur yaitu terdapat 1 remaja yang berumur 12 tahun (6,7\%), 3 remaja berumur 13 tahun (20\%), kemudian 10 remaja berumur 14 tahun (66,6\%) dan 1 remaja berumur 15 tahun (6,7\%). 
Tabel 4. Karakteristik asam urat berdasarkan status gizi

\begin{tabular}{|c|c|c|c|c|}
\hline \multirow[t]{2}{*}{ IMT } & \multicolumn{2}{|c|}{ Jumlah } & \multicolumn{2}{|c|}{$\begin{array}{c}\text { Peningkatan asam } \\
\text { urat }\end{array}$} \\
\hline & (n) & (\%) & (n) & (\%) \\
\hline 26 & 5 & 17 & 1 & 6,7 \\
\hline 27 & 5 & 17 & 2 & 13,3 \\
\hline 28 & 10 & 33 & 5 & 33,3 \\
\hline 29 & 8 & 27 & 5 & 33,3 \\
\hline 30 & 2 & 6 & 2 & 13,3 \\
\hline Total & 30 & 100 & 15 & 100 \\
\hline
\end{tabular}

Berdasarkan tabel 4 dapat dilihat bahwa hasil pengukuran index masa tubuh (IMT) terbanyak adalah 28 berjumlah 10 remaja (33,33\%), kemudian diikuti dengan IMT 29 berjumlah 8 remaja (26,67\%), untuk IMT 26 dan 27 hasilnya sama berjumlah 5 remaja (16,67\%) dan yang paling sedikit adalah dengan IMT 30 berjumlah 2 remaja (6,67\%). Semua hasil dari pengukuran IMT ini merupakan kategori obesitas sesuai dengan kurva BMI untuk Anak laki-laki dan perempuan dari CDC. Untuk jumlah yang mengalami peningkatan asam urat berdasarkan status gizi (IMT) yaitu terdapat 1 remaja dengan IMT 26 (6,7\%), 2 remaja dengan IMT 27 (13\%), 5 remaja dengan IMT 28 (34\%), 5 remaja dengan IMT 29 (33\%), dan 2 remaja dengan IMT 30 (13\%)

Tabel 5. Distribusi responden berdasarkan obesitas

\begin{tabular}{llcllllll}
\hline & \multicolumn{2}{c}{$\begin{array}{c}\text { Asam Urat } \\
\text { Tinggi }\end{array}$} & \multicolumn{2}{c}{$\begin{array}{c}\text { Asam Urat } \\
\text { Normal }\end{array}$} & & Total & $\rho$ & $r$ \\
& (n) & $\mathbf{( \% )}$ & $\mathbf{( n )}$ & $\mathbf{( \% )}$ & $\mathbf{( n )}$ & $\mathbf{( \% )}$ & & \\
\hline Obesitas & 15 & 50 & 15 & 50 & 30 & 100 & 0,115 & 0,294
\end{tabular}

Berdasarkan tabel 5 dapat dilihat bahwa dari hasil pengukuran asam urat pada 30 remaja yang mengalami obesitas hasilnya didapatkan berimbang yaitu sebesar 15 remaja yang mengalami peningkatan asam urat (50\%) dan yang tidak mengalami peningkatan asam urat sebesar 15 remaja (50\%). Dari hasil uji statistik pearson correlation diperoleh nilai signifikan $\mathrm{p}=$ value sebesar 0,115 dan nilai pearson correlation sebesar 0,294. Karena nilai signifikan 0,115 $>0,05$ maka $\mathrm{H}_{1}$ ditolak dan $\mathrm{H}_{0}$ diterima sehingga tidak ada hubungan antara obesitas dengan peningkatan asam urat. 


\section{PEMBAHASAN}

Penelitian ini dilakukan pada siswa dan siswi sekolah menengah pertama yang bersekolah di SMP swasta Manado dari kelas 1 sampai dengan kelas 3 . Sampel yang diambil menggunakan metode consecutive sampling yaitu pengambilan sampel hingga memenuhi total jumlah sampel yang dibutuhkan dan sesuai dengan kriteria inklusi. ${ }^{11}$ Dari hasil uji Pearson Correlation diketahui nilai $r=0,294$ dan nilai $\rho=0,115$ dimana hasil nilai signifikansi $\rho>0,05$ Sehingga Ho diterima. Dari hasil tersebut, tidak ada hubungan antara obesitas dengan peningkatan asam urat. Hasil ini juga didukung berdasarkan nilai (r) atau nilai kekuatan hubungan yang besarnya 0,294 yang menyatakan tidak ada korelasi yang kuat. Hal ini tidak sejalan dengan penelitian yang dilakukan pada anak dan remaja yang mengalami obesitas di Jepang, yang menyatakan bahwa kadar serum asam urat meningkat secara signifikan terhadap mereka yang mengalami obesitas. ${ }^{9}$ Berbagai faktor yang dapat mempengaruhi hasil penelitian tersebut seperti faktor lingkungan, budaya, jenis makanan yang di konsumsi sehari-hari yang berbeda di setiap tempat, aktifitas fisik dari sampel yang diteliti, perbedaan tempat penelitian yang menurut peneliti merupakan penyebab terjadinya perbedaan.

Ditinjau dari teori Oliveira (2012) mengatakan bahwa banyak faktor yang dapat mempengaruhi peningkatan asam urat salah satunya yaitu Obesitas. Ternyata teori tersebut tidak berlaku pada semua umur dan budaya serta pola hidup mereka dalam hal ini yaitu pada remaja yang mengalami obesitas yang diteliti. Untuk dampak dan gejalanya sendiri belum terlihat dini seperti pada orang dewasa. Dampak-dampak peningkatan asam urat yang berkepanjangan dapat menyebabkan gout atau pirai belum dirasakan pada saat remaja meskipun sudah terjadi peningkatan, tetapi merupakan salah satu faktor resiko kedepannya ketika mereka dewasa. ${ }^{13}$ Ditinjau dari segi pola makanan yang didapatkan dari kuisoner oleh peneliti, cenderung mereka yang terjadi peningkatan kadar asam urat mengkonsumsi jenis makanan yang tinggi purin sebanyak 1-3 kali sehari dan 4-5 kali seminggu dalam kesehariannya. Sedangkan mereka yang tidak terjadi peningkatan kadar asam urat cenderung mengkonsumsi jenis makanan purin sebanyak 4-5 kali seminggu dan bahkan tidak pernah dalam kesehariannya. Hal ini sejalan dengan teori yang menyatakan bahwa diet tinggi purin merupakan salah satu faktor peningkatan asam urat. ${ }^{14}$ Namun, peneliti tidak meneliti lebih lanjut mengenai pola makanan tersebut.

Berdasarkan penjelasan diatas, dapat diketahui sebab tidak terdapat hubungan bermakna antara obesitas dengan peningkatan asam urat pada remaja karena berbagai macam faktor yang dapat mempengaruhinya bukan hanya sebatas obesitas saja. Penelitian ini memiliki kelemahan dan keterbatasan antara lain tidak banyaknya sampel yang diteliti akibat sedikitnya jumlah sampel yang bersedia sehingga sangat mempengaruhi hasil dari penelitian, peneliti tidak meneliti lebih lanjut mengenai korelasi antara pola makan dengan peningkatan asam urat. Untuk penelitian selanjutnya dianjurkan untuk melakukan penelitian serupa dengan jumlah sampel yang lebih banyak dan menyeluruh serta pola makan yang dikonsumsi. 


\section{KESIMPULAN}

Berdasarkan hasil penelitian yang telah dilakukan dapat disimpulkan bahwa tidak ada hubungan antara obesitas dengan peningkatan asam urat, jumlah peningkatan asam urat sebagian besar ditemukan pada remaja perempuan yang berumur empat belas tahun.

\section{DAFTAR PUSTAKA}

1. Mazur A, Matusik P, Revert K, Nyankovskyy S, Socha P, Bury BM, et al. Childhood Obesity: Knowledge, Attitudes, and Practices of European Pediatric Care Providers.Pediatrics. 2013:132(1);100-108.

2. Zulfa F. Hubungan Kebiasaan Konsumsi Fast Food Modern Dengan Status Gizi (BB/TB Z-Score) di SD AL-Muttaqin Tasikmaya. FKM-UNSIL; 2011. Available from: http://journal.unsil.ac.id/jurnal/prosiding/9/9fitri_14.pdf.pdf

3. Indonesia. BPPK KemenKes RI. Riskesdas 2010. Jakarta:2010. Di akses tgl: 11 Agustus2013.Diakses di:http://www.litbang.depkes.go.id/sites/download/buku_laporan/lapnas_riskes das2010/Laporan_riskesdas_2010.pdf

4. Indonesia. DepKes RI. Profil Kesehatan Indonesia 2008. Jakarta:2009. Di akses tgl: 11 Agustus 2013. Diakses di:

http://www.depkes.go.id/downloads/publikasi/Profil\%20Kesehatan\%20Indone sia\%202008.pdf

5. Benaroch R. Obesity in Children [internet]. 2012 [updated 2012 July 11; citied 2013 Aug 11]. Available from: http://children.webmd.com/guide/obesity children

6. Childhood Obesity Facts [internet]. 2013 July 10 [updated 2013 July 10; citied 2013 Aug 11]. Available from:

http://www.cdc.gov/healthyyouth/obesity/facts.htm

7. Basics About Childhood Obesity [internet] 2012 April 27 [updated 2012 April 27; citied 2013 Aug 11]. Available from:

http://www.cdc.gov/obesity/childhood/basics.html

8. Qazi Y. Hyperuricemia, eMedicine [internet]. 2012 [citied 2013 August 2013]. Available from: http://emedicine.medscape.com/article/241767overview\#showall

9. Oyama C, Takashi T, Oyamada M, Oyamada T, Ohno T, Miyashita M, et al. Serum Uric Acid as an Obesity-Related Indicator in Early Adolescence. Tohoku J. Exp. Med. 2006: 209(3): 257-262. 
10. Manampiring AE, Bodhy W. Prevalensi Hiperusemia pada Remaja Obese di Kota Tomohon. Universitas Samratulangi; 2010 [citied 2013 Sept 23].

Available from:

http://repo.unsrat.ac.id/251/1/Prevalensi_Hiperurisemia_pada_Remaja_Obese Di_Kota_Tomohon.pdf

11. Sastroasmoro S, Ismael S. Dasar-dasar Metodologi Penelitian Klinis. 4 ed. Jakarta: CV.Sagung seto; 2011. Bab 5, Pemilihan subyek penelitian; hal.99.

12. Oliviera EPD, Burini RC. High Plasma Uric Acid Concentration: Causes and Consequences. Dms J. 2012.4:12.

13. Putra RT. Hiperurisemia. Dalam : Buku Ajar Ilmu Penyakit Dalam. 4. Jakarta: Interna Publishing; 2009. hal. 2550.

14. Lo SF. Reference Intervals for Laboratory Tests and Procedures. In: Kliegman RM, Stanton BF, St.Geme JW, Schor NF, Behrman RE, editors. Nelson Textbook of Pediatrics. 19th ed. Philadelphia: Elsevier Saunders: 2011. CHM e-book. 